\title{
Trace Metal Accumulation in Hair and Skin of the Harbour Seal, Phoca vitulina
}

\author{
C. WENZEL*, D. ADELUNG*, H. KRUSE $\dagger$ and O. WASSERMANN $\dagger$ \\ *Institut für Meereskunde, Abteilung Meereszoologie, Düsternbrooker Weg 20, 2300 Kiel 1, Germany \\ $\dagger$ Institut für Toxikologie, Brunswiker Str. 10, 2300 Kiel 1, Germany
}

\begin{abstract}
Skin and hair samples of harbour seals (Phoca vitulina) found dead along the west coast of northern Germany in 1988 were analysed for total mercury, cadmium and lead. Cadmium and lead concentrations were below the detection limit in most skin samples. The mercury content of the hair (median: $23.1 \mu \mathrm{g} \mathrm{g}^{-1}$ wet wt) was several magnitudes higher than the mercury content of the skin $\left(0.27 \mu \mathrm{g} \mathrm{g}^{-1}\right.$ wet wt). Mercury concentrations in hair samples were significantly higher than lead concentrations $\left(0.54 \mu \mathrm{g} \mathrm{g}^{-1}\right.$ wet $\left.\mathrm{wt}\right)$, which significantly exceeded cadmium levels ( $0.09 \mu \mathrm{g} \mathrm{g}^{-1}$ wet wt). Female seals revealed lower cadmium concentrations in the hair than male seals. Accumulations of metals with age were observed for cadmium and lead in hair samples and for mercury in skin samples of male seals. A connection between metal accumulation and pigmentation or rather moult was clearly recognizable.
\end{abstract}

Pronounced fluctuations in harbour seal populations of the North Sea have frequently occurred in the last few decades (Reijnders, 1986). The mass mortality of seals in 1988 due to infections of herpes- and morbiliviruses (Haas, 1991) led to one of the strongest decreases of marine mammals ever encountered in this area. Although infection was considered a direct cause of death, pollution effects are likely to favour mortality by weakening the immune system. Chronic exposures of organochlorines and trace metals are known to effect the immune system of animals and humans. Mercury, cadmium and lead are particularly pertinent in this respect because of their high toxicities and accumulation properties.

Several investigations have been done on the metal burden of inner organs of marine mammals (Koeman et al., 1973; Koeman et al., 1975; Roberts et al., 1976; Harms et al., 1978; Drescher, 1979; Reijnders, 1980; Honda, et al., 1982; Honda, 1983; Ronald et al., 1984; Yamamoto, 1987) but few data are available concerning trace metal accumulation in the integument of these animals (Honda et al., 1982; Yamamoto, 1987; Hyvärinen \& Sipilä, 1984; Roberts et al. 1976). Previously published results indicate that keratinized tissues such as feathers and human hair are useful indicators of short- or long-term variations in exposure to environmental pollutants. To determine, whether this hypothesis is also true for hair of marine mammals, integument samples of harbour seals were analysed for mercury, lead and cadmium concentrations. Another objective of this paper is to discuss the influence of moult on the accumulation of metals in the hair.

\section{Materials and Methods}

Fur samples were collected from 47 specimens of Phoca vitulina found dead along the west coast of northern Germany in the summer of 1988. The samples originated from the neck regions of the animals. Tissues were stored in metal-free polyethylene bags at $-20^{\circ} \mathrm{C}$. Prior to analysis the samples were thawed just sufficiently to be cut. The hair was carefully removed from the skin with clean stainless steel instruments, washed in acetone, rinsed twice with double distilled water and washed again in acetone (Chatt, 1985; Das, 1981). The hair was subsequently rinsed, filtered and air dried. According to Ellis (1981) and Chatt (1985) exogeneous contaminations are removed by this washing procedure.

Samples were weighed in PTFE-containers. For cadmium and lead analyses the hair as well as the skin was digested under pressure in $\mathrm{HNO}_{3}$ for $4 \mathrm{~h}$ at $165^{\circ} \mathrm{C}$. For total mercury analysis tissues were digested under pressure with a $1: 2 \mathrm{H}_{2} \mathrm{SO}_{4}-\mathrm{HNO}_{3}$ mixture for $3 \mathrm{~h}$ at $165^{\circ} \mathrm{C}$. The digested aliquots were stabilized as described by Korunova \& Dedina (1980) and Lang (1983).

Cadmium and lead were determined by graphite furnace atomic absorption spectrometry. Mercury concentrations were measured using the cold-vapourtechnique.

Prior to analysis the reproducibility of the method was tested and all used chemicals were analysed for metal contaminations. To confirm the accuracy of the analytical procedure standard materials 'Human Hair' (BCR/CRM 397) and 'Pig Kidney' (BCR 186) of the Bureau of Reference were analysed simultaneously with the samples.

Due to matrix effects standard addition calibrations 
TABLE 1

Concentrations of metals in male and female seals of different age classes $\left(\mu \mathrm{g} \mathrm{g}^{-1}\right.$ wet wt).

\begin{tabular}{|c|c|c|c|c|c|c|c|c|}
\hline & \multicolumn{2}{|c|}{$\mathrm{Cd} /$ hair } & \multicolumn{2}{|c|}{$\mathrm{Pb} /$ hair } & \multicolumn{2}{|c|}{$\mathrm{Hg} /$ hair } & \multicolumn{2}{|c|}{$\mathrm{Hg} /$ skin } \\
\hline & Pups & Adults & Pups & Adults & Pups & Adults & Pups & Adults \\
\hline $\begin{array}{l}0^{*}: \\
\text { Median }\end{array}$ & 0.10 & 0.17 & 0.4 & 0.6 & 9.0 & 19.8 & 0.09 & 0.38 \\
\hline Mean & $\begin{array}{r}0.09 \\
+0.03\end{array}$ & $\begin{array}{r}0.17 \\
\pm 0.12\end{array}$ & $\begin{array}{r}0.5 \\
\pm 0.1\end{array}$ & $\begin{array}{r}0.6 \\
\pm 0.3\end{array}$ & $\begin{array}{r}22.1 \\
\pm 20.3\end{array}$ & $\begin{array}{c}25 \\
+16.1\end{array}$ & $\begin{array}{r}0.12 \\
\pm 0.08\end{array}$ & $\begin{array}{r}0.44 \\
\pm 0.31\end{array}$ \\
\hline $\begin{array}{l}\text { Q: } \\
\text { Median }\end{array}$ & 0.11 & 0.08 & 0.9 & 0.4 & 13.6 & 32.1 & 0.29 & 0.33 \\
\hline Mean & $\begin{array}{r}0.13 \\
\pm 0.11\end{array}$ & $\begin{array}{c}0.1 \\
\pm 0.09\end{array}$ & $\begin{array}{r}1.1 \\
\pm 0.8\end{array}$ & $\begin{array}{r}0.6 \\
\pm 0.3\end{array}$ & $\begin{array}{r}21.2 \\
\pm 23.4\end{array}$ & $\begin{array}{r}55.9 \\
+61.3\end{array}$ & $\begin{array}{r}0.34 \\
+0.18\end{array}$ & $\begin{array}{r}0.59 \\
+0.67\end{array}$ \\
\hline
\end{tabular}

were used for lead and mercury, whereas cadmium could be determined by linear calibration. Since most data had distributions other than gaussian, all statistical calculations are based on medians instead of means. Metal concentrations were tested for significance using Kruskal-Wallis-H-tests, Wilcoxon and Friedman-tests.

\section{Results}

The results of cadmium, lead and mercury in skin and hair tissues are summarized in Table 1. Heavy metal concentrations are expressed as means and medians and all values are based on wet weight. Concentrations cited in the text are expressed as medians. Cadmium and lead contents of the skin were below detection limits (Cd: $0.002 \mu \mathrm{g} \mathrm{g}^{-1}$; Pb: $0.04 \mu \mathrm{g} \mathrm{g}^{-1}$ ) in most cases. Only one seal showed measurable cadmium concentrations and two pups exhibited higher lead concentrations $\left(0.3 \mu \mathrm{g} \mathrm{g}^{-1} ; 0.1 \mu \mathrm{g} \mathrm{g}^{-1}\right)$ than all other animals.

A comparison of metal contents in hair samples revealed significantly increasing concentrations with $\mathrm{Cd}<\mathrm{Pb}<\mathrm{Hg}(\mathrm{p}<0.001)$.

\section{Sex and age differences}

Cadmium concentrations were higher in the hair of adult males than in adult females $(p<0.05)$. A great variability was apparent in the mercury content of both female and male pups and adult females (Table 2).

There were significant positive correlations $(p<0.02)$ of lead and cadmium in hair and mercury in skin as a function of male seal age, weight and length. No such correlations were found in female seals (Fig. 1).

\section{Metal content and pigmentation of the hair}

Significant differences between the metal content of hair samples of different colours $(p<0.05)$ were observed. Yellow to brown coloured hair contained highest cadmium $\left(0.29 \mu \mathrm{g} \mathrm{g}^{-1}\right)$ and lead concentrations $\left(0.9 \mu \mathrm{g} \mathrm{g}^{-1}\right)$ compared to whitish (Cd: $0.09 \mu \mathrm{g} \mathrm{g}^{-1} ; \mathrm{Pb}$ : $0.5 \mu \mathrm{g} \mathrm{g}^{-1}$ ) and blackish hair (Cd: $0.06 \mu \mathrm{g} \mathrm{g}^{-1} ; \mathrm{Pb}: 0.4$ $\left.\mu \mathrm{g} \mathrm{g}^{-1}\right)$. No such trend was noted for mercury. Blackish and whitish coloured hair showed similar metal concentrations.

\section{Correlations between different elements}

Lead concentrations were positively correlated with cadmium $(p<0.001)$ and mercury $(p<0.05)$ in sub-

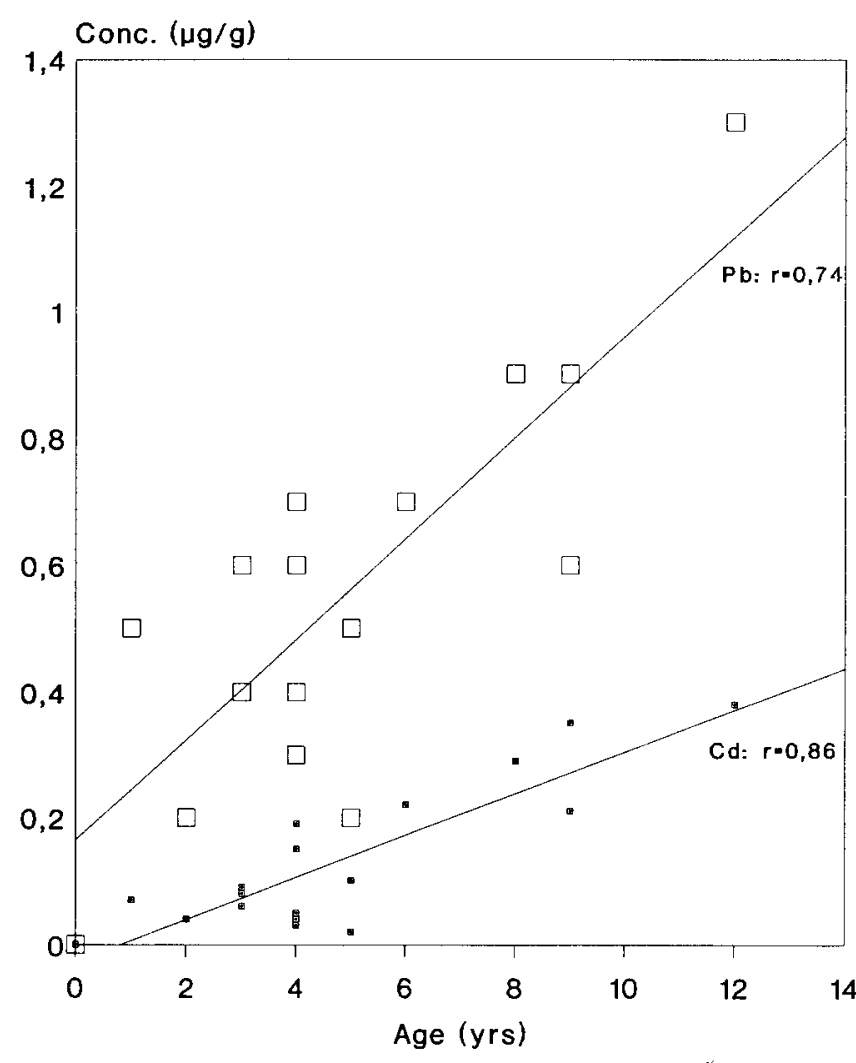

Fig. 1 Cadmium and lead concentrations in subadult (1-3 yr) and adult ( $>3$ yr) male seals; $r=$ correlation coefficient.

TABLE 2

Concentrations of metals in hair and skin of harbour seal in 1988 $\left(\mu \mathrm{g} \mathrm{g}^{-1}\right.$ wet wt).

\begin{tabular}{lrrrrrr}
\hline & \multicolumn{2}{c}{ Cd } & \multicolumn{2}{c}{$\mathrm{Pb}$} & \multicolumn{2}{c}{$\mathrm{Hg}$} \\
& Hair & Skin & Hair & Skin & Hair & Skin \\
Median & 0.09 & $<0.002$ & 0.5 & $<0.04$ & 23.1 & 0.27 \\
Means & 0.12 & $<0.002$ & 0.6 & $<0.04$ & 33.5 & 0.40 \\
& \pm 0.09 & & \pm 0.4 & & \pm 38.5 & \pm 0.43 \\
\hline
\end{tabular}

adult and adult male seal hair samples. No correlations were found between mercury and cadmium concentrations of male seals and between different metal contents of female seals.

\section{Discussion}

There were great differences between the accumulation properties of cadmium, lead and mercury in skin and hair samples. For example cadmium and lead were 
below detection limits in skin samples, whereas considerable amounts of mercury were found in this tissue. Compared to mercury levels in harbour seal liver and kidney, however (Koeman et al., 1973; Roberts et al., 1976; Drescher, 1979; Reijnders, 1980; Harms, 1983), the mercury content of the skin was low indicating that the skin of marine mammals cannot be considered a target organ of metal accumulation.

Hair samples, on the other hand, revealed metal concentrations similar to liver and kidney tissues of previously published investigations (Koeman et al., 1975; Roberts et al., 1976; Harms et al., 1978; Risebrough, 1978; Drescher, 1979; Duinker, 1979; Harms, 1983). In particular mercury accumulates in the marine food chain leading to 100-1000 times higher mercury concentrations in seal hair than in some species of prey (Kruse \& Krüger, 1984; Claussen, 1988). Similar mercury accumulation has been described by Drescher (1979) and Hapke (1984). Seal hair, therefore, appears to play an important role in the accumulation of heavy metals. Keratinized tissues such as bird feathers and human hair are known to be reliable indicators of metal pollution (Jenkins, 1979; Phelps, 1980; Gochfeld, 1991). Marine mammal hair may also be useful in this regard.

Unlike human hair seal hair grows rapidly and has a correspondingly different pollutant accumulation pattern. In addition, marine mammal hair does not grow continuously like in humans but is renewed over a relatively short period in an annual moult (Bigg, 1981; Ling, 1984). All animals analysed were found dead between the end of August and the end of September and therefore originated from different moult stages (Bonner, 1972). Our results indicate that this particular mode of hair growth influences the distribution of metals in hair tissue. The timing of moult seem to be an important factor in the accumulation of metals with age. Bigg (1981) found, that adult seals moult later than subadult seals. This delay might have caused the higher cadmium concentrations in the hair of adult male seals compared to subadult males.

Sex and reproductive stage of animals may also influence the trace metal content of seal hair. According to Ling $(1965,1984)$ moult is closely linked to breeding in female seals. Due to inhibitory mechanisms during lactation, moult occurs later in breeding female seals than in non-breeding seals (Ling, 1965). It is possible that the different timing of moult accounts for the variability in trace metal contents especially of female hair. These animals also excrete metals via transplacental transport and lactation, which in turn may influence the metal content in pups and breeding female seals (Holden, 1978; Honda, 1983).

The observed link between metal concentration in seal hair and pigmentation is probably a function of hair age. Brownish and yellow hair can be considered dead material which is no longer connected to hair follicles and which is about to be shed (Stede, pers. comm.). All other hair colours represent newly grown hair. It can be seen clearly from the results that the deposition of metals was complete in the dead hair material, while in at least some seals hair was still growing so metals were presumably still being accumulated. This hypothesis was most evident in one particular seal, which was found dead while moulting. This animal had a combination of still growing short, black hair and old fully grown, yellow hair. The analysis of both hair types revealed significantly higher cadmium and lead concentrations in old yellow hair than in growing black hair. This corresponds to the metal concentrations of similar pigmentated hair of other seals analysed in this study (including female and male seals of all age classes). These results as well as the comparable concentrations of black and whitish hair indicate that pigmentation is not important for trace metal accumulation in seal hair but the different growth stages of hair strongly influences the metal concentration in this tissue.

It is possible that the influence of moult on the metal accumulation in hair biases the relationship between metal accumulation and age found in male seals. For example, the oldest male seals showed yellow, dead hair and therefore revealed the highest cadmium and lead concentrations. If these seals were excluded from the consideration of metal accumulation with age, no correlations were found between age and metal concentrations in male seals. The influence of moult on metal accumulation with age could also be observed in female seals. The oldest animals showed still growing whitish coloured hair carrying extremely low cadmium and lead concentrations. Consequently the metal content of seal hair can be highly variable due to reproductive effects and moult. For these reasons hair of animals collected during the late breeding/moulting season cannot be used as indicator tissues for metal pollution. Further investigations have to be done on metal accumulation in seal hair between two moults in order to discuss the indicator function of this tissue.

The consideration of metal concentrations in seal hair, however, is useful, if metabolic processes are to be taken into account. Accumulation of metals in hair indicates that considerable amounts of toxic substances are excreted during the moult so that hair may function as a detoxifying organ for seals.

Detoxifying mechanisms also involve antagonistic effects between essential and non-essential metals. Zinc is known to exhibit detoxifying effects against cadmium intoxications. The same is true for selenium and mercury (Rohbock, 1984; Ronald, 1984). Synergistic effects may also occur between non-essential metals intensifying the toxic properties of these compounds. Such combined effects were described by Rohbock (1984) and Wickelein (1984) between mercury and lead and between cadmium and lead. We observed significant correlations between these elements in hair of male animals indicating that these particular effects may also be valid for harbour seals. Further investigations concerning the correlation of metals in hair and inner organs are needed to confirm this hypothesis.

Bigg, M. A. (1981). Harbour seal Phoca vitulina L., 1758 and Phoca larga P.. 1911. In Handbook of Marine Mammals, Vol. 2: Seals (S. H. Ridgeway \& R. J. Harrison, eds), pp. 1-26. Academic Press, London. 
Bonner, W. N. (1972). The grey seal and common seal in European waters. Oceanogr. Mar. Biol. Ann. Rev. 10, 461-507.

Chatt, A. (1985). Health-related monitoring of the trace element pollutants using nuclear techniques, IAEA-TECDOC-330, International Atomic Energy Agency, Vienna, 1985, pp. 33-49.

Claussen, T. (1988). Levels and spacial distribution of trace metals in dabs (Limanda limanda) of th southern North Sea. Mitt. Geol.Paläont. Inst. Univ. Hamburg 65, 467-496.

Das, H. A. (1981). International neutron activation analysis of human hair and related radiotracer experiments on washing and leaching. Report ECN-107, Netherlands Energy Research Foundation, Petten, 1981.

Drescher, H. E. (1979). Biologie, Ökologie und Schutz der Seehunde im Schleswig-Holsteinischen Wattenmeer. Beiträge zur Wildbiologie, Landesjagdverband SH, Meldorf.

Duinker, J. C., Hillebrand, M. Th. J. \& Nolting, R. F. (1979). Organochlorines and metals in harbour seals (Dutch Wadden Sea). Mar. Pollut. Bull. 10, 360-364.

Ellis, K. J. (1981). Amer. J. Indust. Med. 2, 32-33.

Gochfeld, M. (1991). Effects of color on cadmium and lead levels in avian contour feathers. Arch. Environ. Contam. Toxicol. 20, 523526.

Haas, L. (1991). Detection of phocid distemper virus RNA in seal tissues using slot hybridization and the polymerase chain reaction amplification assay: Genetic evidence that the virus is distinct from canine distemper virus. J. Gen. Virol. 72, 825-832.

Hapke, H. J. (1984). Metallbelastungen von Futter- und Lebensmitteln, Akkumulation in der Nahrungskette. In Metalle in der Umwelt (E. Merian, ed.), pp. 37-40. Basel, Verlag Chemie.

Harms, U., Drescher, H. E. \& Huschenbeth, E. (1978). Further data on heavy metals and organochlorines in marine mammals from german coastal waters. Meeresforschung 26, 153-161.

Harms, U. (1983). Analytik und Vorkommen anorganischer und organischer Ouecksilberverbundungen in Meeres- und Landtieren. Fresenius Z. Anal. Chem. 316, 600-603.

Holden, A. V. (1978). Pollutants and seals-A review. Mammal Rev $8(1,2), 53-66$

Honda, K., Tatsukawa, R. \& Fujiyama, T. (1982). Distribution characteristics of heavy metals in the organs and tissues of striped dolphin, Stenella coeruleoalba. Agric. Biol. Chem. 46(12), 30113021.

Honda, K. (1983). Heavy metal concentration in muscle, liver and kidney tissue of striped dolphin, Stenella coeruleoalba, and their variations with body length, age and sex. Agric. Biol. Chem. 47(6) 1219-1228.

Hyvärinen, H. \& Sipilä, T. (1984). Heavy metals and high pup mortality in the Saimaa ringed seal population in eastern Finland. Mar. Pollut. Bull. 15(9), 335-337.

Jenkins, D. W. (1979). Biological monitoring of toxic trace metals.
Environmental Protection Agency, Publication No. 600/3-80-089, Washington, DC.

Koeman, J. H., Peeters, W. H. M. \& Koudstaal-Hol, C. H. M. (1973) Mercury-selenium correlations in marine mammals. Nature $\mathbf{2 4 5}$, 385-386.

Koeman, J. H., de Goeij, J. J. M. \& van Haaften, J. L. (1975). Mercury and selenium in marine mammals and birds. Sci. Tot. Environ. 3, 279-287.

Korunova, V. \& Dedina, J. (1980). Determination of trace concentrations of mercury in biological materials after digestion under pressure in nitric acid catalysed by vanadium pentoxide. Analyst $105,48-51$.

Kruse, R. \& Krüger, K.-E. (1984). Untersuchungen von Nordseefischen auf Gehalte an toxischen Schwermetallen und Chlorierten Kohlenwasserstoffen im Hinblick auf lebensmittelrechtliche Bestimmungen. Archiv für Lebensmittelhygiene 35(6), $128 \mathrm{ff}$.

Lang, D. (1983). Untersuchungen zur Populationsdynamik von Seehunden im Schleswig-Holsteinischen Wattenmeer. Diplomarbeit an der CAU Kiel (Institut für Haustierkunde).

Ling, J. K. (1965). Hair growth and moulting in the southern elephant seal, Mirounga leonina (Linn.). In Biology of the Skin and Hair Growth (A. G. Lyne \& B. F. Short, eds), pp. 525-544. Sydney.

Ling, J. K. (1984). Epidermal cycles and moulting in marine mammals. Acta Zoologica Fennica 171, 23-26.

Phelps, R. W. (1980). Interrelationships of blood and hair mercury concentrations in a north American population exposed to methylmercury. Archives Environ. Health 35, 161-168.

Reijnders, P. J. H. (1980). Organochlorine and heavy metal residues in harbour seals from the Wadden Sea and their possible effects on reproduction. Netherl. J. Sea Res. 14(1), 30-65.

Reijnders, P. J. H. (1986). Reproductive failure in common seals feeding on fish from polluted coastal waters. Nature 324, 456-457.

Risebrough, R. W. (1978). Pollutants in marine mammals. A literature review and recommendations for research. Marine Mammal Commission. U.S. Department of Commerce, National Technical Information Service, PB-290 728, Washington, DC.

Roberts, T. M., Heppleston, P. B. \& Roberts, R. D. (1976). Distribution of heavy metals in tissues of the common seal. Mar. Pollut. Bull. 7 , 194-196.

Rohbock, E. (1984). Gemeinsames Vorkommen und Kombinationswirkungen. In Metalle in der Umwelt (E. Merian, ed.), pp. 111-115. Verlag Chemie.

Ronald, K., Frank, R. J. \& Dougan, J. (1984). Pollutants in harp seals (Phoca groenlandica). II. Heavy metals and selenium. Sci. Tot. Environ. 38, 153-166.

Wickelein, A. (1984). Belastung der Umwelt durch Schwermetalle. Vortrag Rotary Club Bremen-Vegesack, 1.2.1984.

Yamamoto, Y. (1987). Tissue distribution of heavy metals in weddel seals (Leptonychotes weddellii). Mar. Pollut. Bull. 18, 164-169. 